\title{
Make your
}

\section{dreams a reality}

Entering Higher Education as a mature student PHOTO REDACTED DUE TO THIRD PARTY RIGHTS OR OTHER LEGAL ISSUES 


\section{Whoever you are, and whatever} stage rou are at in life, taking a Figher Folucation course could help you get where you want to be.

The qualifications you get could be the way to move on in your career or even start in a new direction. All this can mean more money - over the course of their working life, the holder of an undergraduate degree can expect to earn, on average, comfortably in excess of $£ 100,000$ more, net of taxes and in today's valuation, than a similar person with two or more A levels - and a job that gives you more satisfaction and more choices in your life.

It's never too late to take this step and with so many different options for taking courses - full time, part time or even online - you can fit in studying with the rest of your life. Also, with the financial help on offer and the chance to carry on earning while you learn, a course may be much more within reach than you think.

Who is it for?

Higher education is for anyone who wants to further their learning or open up new possibilities at any stage of their life, particularly if you:

- left school at 16 but are now looking to get new qualifications

- want to further your career

- want to make a complete career change

- want to pursue a specialist interest, for example in photography

- have children and want to return to studying. 


\section{Why choose Figher Fducation?}

Just look at the range of benefits

you could get from going into higher

education - for you personally, for

your career and your bank balance!

Higher education could be your path

to a more fulfilling and exciting

new future.

\section{Improve your prospects at work}

A higher education qualification can make a dramatic difference to your career. The right qualification can give you the skills to progress in your current career, putting you in the running for a senior or managerial role.

In higher education, you learn many important skills in researching, analysing and applying what you find - all of which are of great value to an employer. By completing a course, you also show your commitment and willingness to keep learning.

\section{Change your life}

If you are looking for a change, higher education can set you on a new career path. Maybe you fancy re-training to become a teacher? Or a nurse? Or an accountant? There are many different courses, and more financial help available than you may think, to help you make your dreams a reality.

\section{Find it easier to get a new job}

Your higher education qualification makes you more employable. Recent forecasts by the Institute of Employment Research showed that of the 13 million jobs expected to become vacant between
2007 and 2017, half - that's 6.5 million - will be in occupations most likely to demand graduates. You are less likely to be out of work if you have a higher education qualification.

\section{Broaden your horizons}

There's a lot more to higher education than just studying. You'll find that going to university or college will introduce you to new people, new challenges, new experiences - perhaps even new places! Higher education is completely different from school. You may have a mix of lectures, seminars and tutorials, or study at a distance, and you will learn a variety of skills, depending on which course you opt for. You may be able to use sports facilities, join clubs and societies, and develop new interests and hobbies.

You will find you gain more confidence to deal with whatever comes up in the future. You will also come into contact with a wide range of people, from different places and backgrounds.

\section{Surprised?}

University or college isn't just for 18-year-olds straight from school. You'll be surprised how many of your fellow students are in a similar position to you - returning to study, often working and learning at the same time. In fact, $68 \%$ of higher education students in the UK (and $59 \%$ of undergraduate students) are aged over 20, and around $40 \%$ of students choose to study part time or through flexible learning. 


\section{Case study}

Name: Sonia Pidduck

Age: 28

Course: BA degree in Business

and Administration

Sonia grew up in Welwyn Garden City, and as neither of her parents had gone on to higher education, she stayed at school to complete her A levels and went on to become a full-time secretary for a recruitment consultancy. Though she enjoyed the job, she realised that her prospects weren't great.

After two graduate colleagues told her all about university life, she decided to start a degree in Business and Administration at Luton University. She worked seven days a week to pay her fees and received a student loan and hardship fund from the Government to help out. It was worth the money, as she graduated in 2001 with a first class Honours degree!

Sonia thinks that if she hadn't done her degree, she would probably be in the same company that she was at before and frustrated at the lack of opportunity. She says: "I am even happier now that I am reaping the benefits of my studies. It just goes to show that sometimes you do have to bide your time before being given the opportunity and that patience is key!"

"I am reaping the benefits of

my studies. It just goes to show

that sometimes you do have to bide your time before being

given the opportunity and that patience is key!" 


\section{Choosing a course}

Whether you need a specific, work-related qualification to help you get on

at work, or want to broaden your mind and understanding of a subject,

with over 50,000 courses to choose from there is bound to be one that's

right for you.

To give you an idea of some of the courses that are available and for advice on choosing a course, visit www.ucas.com

\begin{tabular}{|c|c|c|c|}
\hline Type of qualification & What is it? & How long does it take? & Where next? \\
\hline $\begin{array}{l}\text { Fonours degree } \\
\text { From Aesthetics to } \\
\text { Zoology: almost any } \\
\text { subject you can think of. }\end{array}$ & $\begin{array}{l}\text { A subject-based } \\
\text { qualification, and the } \\
\text { most common kind in } \\
\text { higher education. } \\
\text { Sandwich courses include } \\
\text { a year at work. }\end{array}$ & $\begin{array}{l}\text { Three to five years full } \\
\text { time. Up to eight years } \\
\text { part time or by flexible } \\
\text { learning. }\end{array}$ & $\begin{array}{l}\text { You could go on to gain } \\
\text { other professional } \\
\text { qualifications such as a } \\
\text { Master's degree or PhD. }\end{array}$ \\
\hline $\begin{array}{l}\text { Foundation Degree } \\
\text { Subjects in areas such } \\
\text { as Business, Computing, } \\
\text { Education, Engineering, } \\
\text { Health, Hospitality, } \\
\text { Science, Technology and } \\
\text { the Arts. }\end{array}$ & $\begin{array}{l}\text { A vocation-focused } \\
\text { qualification which } \\
\text { combines academic and } \\
\text { work-based learning. }\end{array}$ & $\begin{array}{l}\text { If taken full time, two } \\
\text { years or equivalent part } \\
\text { time. Other modes of } \\
\text { delivery include distance } \\
\text { learning and online } \\
\text { options. }\end{array}$ & $\begin{array}{l}\text { You could progress to } \\
\text { other professional } \\
\text { qualifications or the } \\
\text { Foundation Degree should } \\
\text { link with a specified } \\
\text { Honours degree, which } \\
\text { you may have the } \\
\text { opportunity to access. }\end{array}$ \\
\hline $\begin{array}{l}\text { Higher National } \\
\text { Diploma / Certificate } \\
\text { (HND / HNC) } \\
\text { Subjects ranging from } \\
\text { Engineering and } \\
\text { Computing to Hospitality } \\
\text { or Care, Dance } \\
\text { and Graphics. }\end{array}$ & $\begin{array}{l}\text { Vocational qualifications, } \\
\text { available in a wide range } \\
\text { of subjects. }\end{array}$ & $\begin{array}{l}\text { HNC } \\
\text { One year full time } \\
\text { Two years part time. } \\
\text { - HND } \\
\text { Two years full } \\
\text { time, longer part time. }\end{array}$ & $\begin{array}{l}\text { You can progress onto } \\
\text { an Honours degree. }\end{array}$ \\
\hline $\begin{array}{l}\text { National Vocational } \\
\text { Qualification } \\
\text { There are NVQs relating } \\
\text { to most jobs and } \\
\text { industries. }\end{array}$ & $\begin{array}{l}\text { A job-related qualification } \\
\text { available in a wide range } \\
\text { of subjects relating to } \\
\text { most jobs and industries. }\end{array}$ & $\begin{array}{l}\text { Several years, depending } \\
\text { on the level you choose } \\
\text { (up to Level 5). Most } \\
\text { NVQs are taken through } \\
\text { your workplace. }\end{array}$ & \\
\hline $\begin{array}{l}\text { Diploma of HW } \\
\text { Many subjects, including } \\
\text { Accounting, Construction, } \\
\text { Engineering, Nursing, } \\
\text { Science and Textile Design. }\end{array}$ & $\begin{array}{l}\text { Very similar to an } \\
\text { Honours degree, but } \\
\text { with less content. }\end{array}$ & Two years full time. & $\begin{array}{l}\text { You can convert your } \\
\text { Diploma of HE to a } \\
\text { degree by studying } \\
\text { for an extra year. }\end{array}$ \\
\hline
\end{tabular}




\section{What do I need to get on a course?}

It all depends on what you want to study and where. Many courses ask for two or three A levels or equivalent qualifications such as a BTEC National Diploma, plus GCSE Maths and English. But there are also many courses that will be more interested in your previous experience and skills than formal qualifications, as these show that you have the potential to succeed.

You can check the entry requirements of courses you are interested in with the university or college direct. For full-time courses you can also check the UCAS website at www.ucas.com or call 08714680468 . To search, review and compare university subjects, and find out what students thought of their studies, including results of the National Student Survey, go to www.unistats.com.

This site brings together official information on UK higher education and could help you make choices about what and where to study.

For Open University courses, there are no educational qualifications to get in. The courses are open to everyone.

\section{What if I don't have the right qualifications?}

Don't worry - you can still get into higher education. You just need to do an Access to Higher Education course first. You can do this at your local college, and it takes one year full time or two years part time to complete. The course will cover a broad subject area, such as science or business, and give you a qualification and experience equivalent to $A$ levels.

The costs of the course are kept to a minimum, and can often be paid for by your local authority.

\section{For more information}

Contact learndirect on 0800100900 or visit www.learndirect.co.uk, or look at the UCAS Access course database at www.ucas.com/access 


\section{Vocational qualifications \\ for Higher Fducation courses}

Depending on the qualifications and experience you already have, you may need to do some more study before you can get on a higher education course. You might choose to study A levels or try an Access to Higher Education course. Or you could take vocational job-related or work-based - qualifications as a route to some degrees.

This diagram shows some of the routes towards getting the qualifications for a higher education course:

- the traditional route: GCSEs and A levels

- the Advanced Diploma

- job-related courses, including BTEC National Diplomas and A levels in job-related subjects - these are more practical and focus on a particular job

- the work-based route, including vocational qualifications (e.g. NVQs) and Apprenticeships, which involve learning at work or on a work placement.

Just some of the paths you could follow are shown here, but remember the routes shown are very flexible:

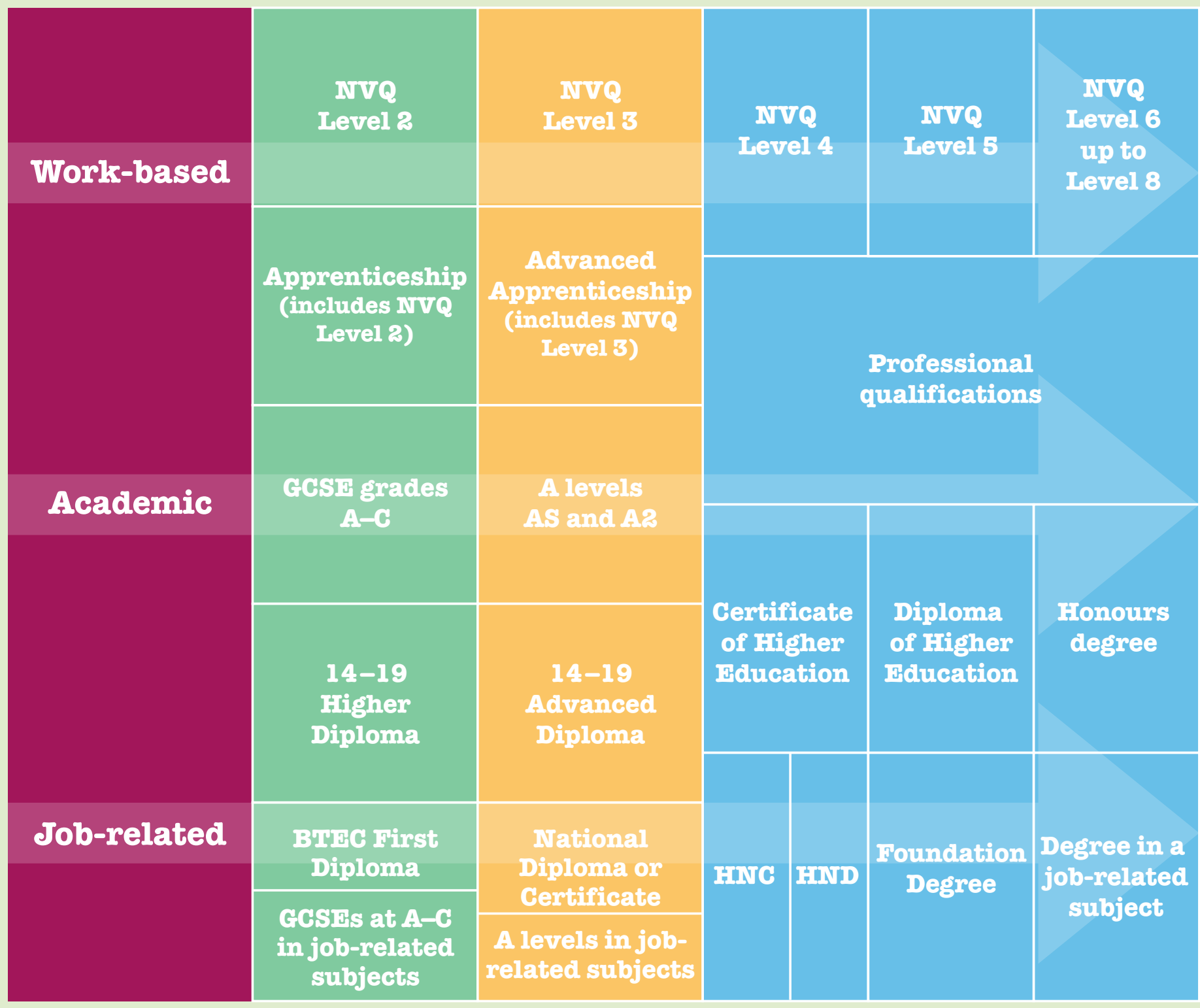


All the different qualifications are grouped into 'levels', depending on the knowledge, skills and understanding they require. BTEC National Diplomas and National Certificates, Advanced Apprenticeships and NVQs at Level 3 are all at the same level as A levels. This means that any of them can be used to get onto many degree courses.

They can also be a way to get onto a Foundation Degree, HNC or HND, NVQ Level 4 or other higher education course.

You may be able to get your previous work experience and skills formally recognised through APEL (accreditation of prior experiential learning). This can be accepted instead of formal qualifications to show you could cope with a higher education course.

Check with the college or university you are thinking of applying to about which qualifications they will accept.

\section{Apprenticeships}

You can join an Apprenticeship or Advanced

Apprenticeship in any of 180 different subjects.

Find out more from www.apprenticeships.org.uk

\section{The advantages of a job-related or work-based} route: If you are hoping to change or improve your career, then in many cases job-related or work-based qualifications can be highly relevant.

Get an advantage in the job market: Vocational qualifications can really help you on your way up the career ladder. They give you the specific knowledge and skills for your work. Courses such as NVQs and Foundation Degrees have been designed with employers. This means they give you exactly what employers are looking for - and thus a much better chance of getting the job you want.

Gain work experience: Work-based qualifications involve learning while doing the job, and most jobrelated courses include a work placement. Either way, you get real experience as well as knowledge and understanding.

Continue earning: Importantly, you can choose to learn or study while working. You can continue to earn and avoid any worries about student debts. It is also worth asking your employer about any support they can give towards the cost of your course. They may be happy to help, especially if it will boost your skills at work.
For a work-based qualification, you mainly learn on the job, perhaps spending some time out at college, so you're earning a full time wage. Job-related courses can be studied full time, but there are plenty of options. Many people study part time alongside their work. They may study by day release at college, in weekend or evening tutorials and lectures, or by distance or online learning at home. If your employer has signed up to the Skills Pledge, this means they have pledged to raise the level of their employees' qualifications to at least Level 2.

\section{Your way of learning}

Your choice of course also depends on the way you prefer to learn. Job-related and work-based qualifications are more hands-on and practical, rather than based on classroom theoretical learning.

With job-related and work-based courses, you also do not need to do as many exams. Work-based qualifications are assessed at work. You are judged on how well you can do the job itself, and often a portfolio of evidence that you put together. On jobrelated courses you are mainly assessed through assignments and practical work.

\section{Find your own route into Higher Education}

The whole system is quite flexible. You don't have to work steadily through each level to qualify for the next. For instance, you may be able to start straight on a Level 3 NVQ without doing Level 2. And you can move on to a course on a different route at any point - whatever is right for you.

There is also a lot of flexibility about how long you spend studying for each qualification.

An example: Mark left school with no qualifications and was working as a care assistant. When he decided he wanted to train as a nurse, he started studying for an NVQ in Care. Beginning with Level 1 , he then gained a Level 3 NVQ, which opened the door to a Diploma in Nursing and an NHS bursary. Even when he had qualified, Mark wanted to continue studying for a better salary and prospects for promotion. He studied part time for the extra modules to convert to a Nursing degree. 


\section{How can}
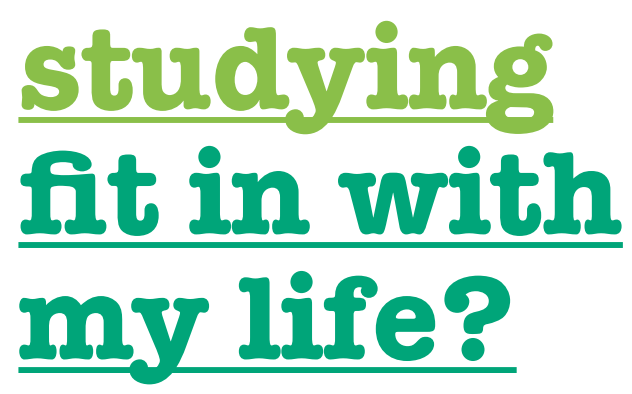

\section{There are lots of different ways}

\section{you can return to studying, so you}

can organise it around the rest of

\section{your life.}

\section{Do I have enough time?}

Part-time or flexible learning might be right for you if you already have other commitments in your life, or you want to continue earning while you learn. Flexible learning means spending less time at university or college and, depending on the course, you may be able to study on your own at home or in your workplace.

\section{Do I have to live near the university or college?}

Not necessarily - another option is distance learning (also known as home study or correspondence course). This is usually done part time and from home or through work. You won't attend classes, but you'll receive course materials in the post instead.

One example of distance learning in higher education is the Open University. On its courses, you will receive support throughout the course, through your nearest regional centre, where you can also mix with other students and meet with your personal tutor.

\section{How can I study and look after my children?}

It is possible to study for a higher education qualification and spend time with your family too. If you have young children, check whether your university or college has crèche or nursery facilities. It is important that you have enough time to study without being distracted.

You may find it easier to spread the course over a longer period and study part time.

Remember that there are lots of other people in the same position as you. You're not alone, and there is help available. For example, you may be entitled to a grant to help pay for childcare while you are studying.

\section{Thinking of studying full time?}

Almost all courses are open to you if you can study full time. One advantage is that you can complete the course and gain your qualification in a shorter time. This makes it ideal if you can afford to live on the grants and loans available, and any savings or other money you have. Many full-time students also take on part-time work in the evenings or at weekends to help out. There is more information on the financial help you can get in the next section.

Studying full time usually means giving up what you are already doing. So if you are hoping to use your new qualification to get further in your job, you may need to talk to your employer about taking a few years out to study. 


\section{What does full-time study involve?}

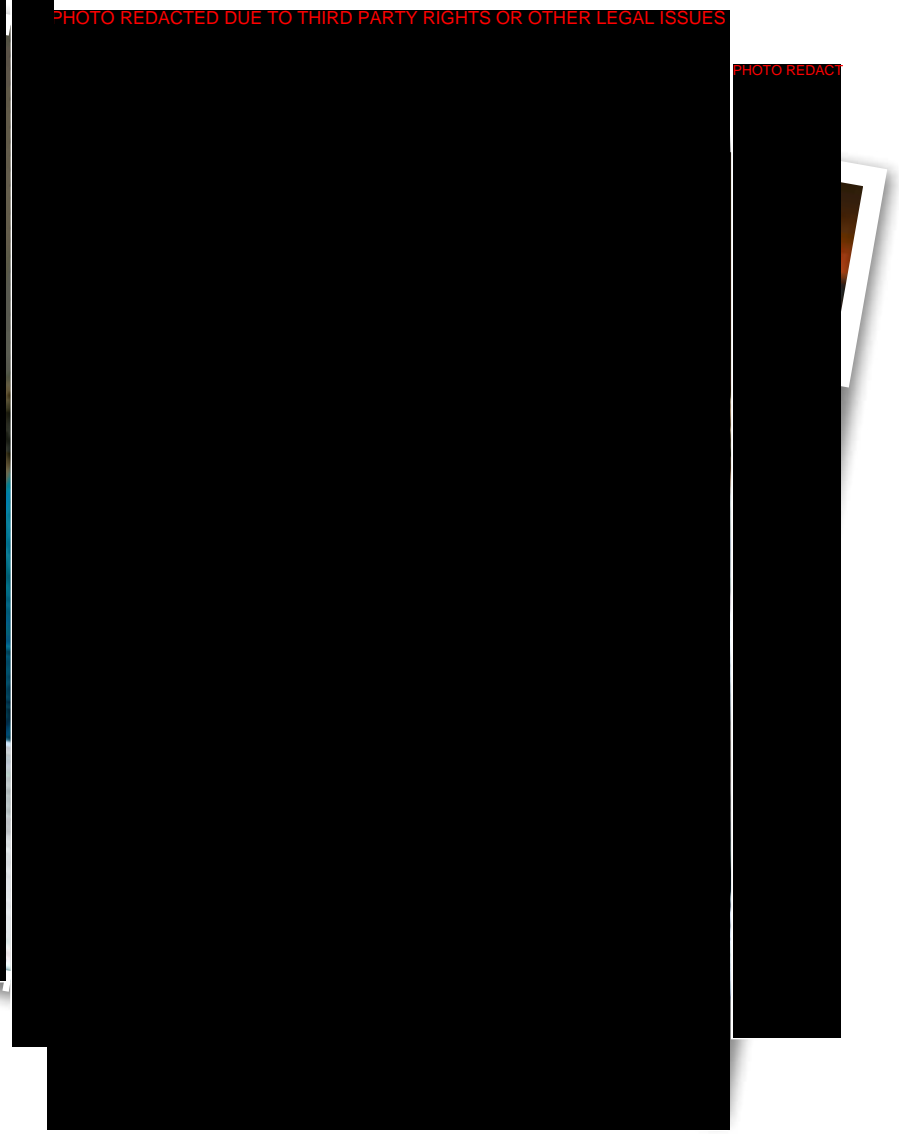

You will have to attend university or college three to four days a week, with lectures, seminars and tutorials on most days. The course might involve practical work, such as laboratory work, if you are doing a science course.

\section{Thinking of studying part time?}

Becoming a full-time student is not the only option. Part-time study can be the ideal answer if you:

- need to be around at home to look after your family

- need to keep on earning to cover your financial commitments

- are in a job that you hope to continue and progress in

- prefer a less pressurised way to learn.

You can study part time on many courses - many Honours degrees, Foundation Degrees, HNDs and HNCs are offered to part-time students. And some kinds of courses, like NVQs, are usually done over a number of years part time.

If getting to college or university is difficult, then distance learning and online options are also available for many kinds of qualification, so you can continue to work full time while you study.

Studying on top of working may sound like hard going - but it can be well worth the time and effort. You will continue to reap the rewards for the rest of your life.

\section{What does part-time study involve?}

You spend the same number of hours on your course as a full-time student, but the hours are spread over a longer period, so studying takes up fewer hours each week. The total time you spend in lectures, seminars and on practical work at university or college is the same as for the equivalent full-time course.

The number of hours each week varies depending on the particular course - often $50 \%$ or $75 \%$ of a full-time timetable.

\section{Can your employer help?}

It could be well worth talking to your employer about your plans to study. Some employers are keen to support their employees in gaining qualifications, and they may give you time off to study, or even help with the costs of the course. 


\section{Help for full- time students}

\section{This information only applies to}

students living in England.

There are two main costs involved - tuition fees and living expenses:

- Tuition fees cover the cost of the course.

- Living expenses cover the cost of accommodation, food, books, clothes and so on.

The good news is that you can get support from the Government with both, in the form of grants and loans. Universities are also offering additional help to students via bursaries and scholarships.

Read on to find out what could be available.

\section{Tuition fees}

In 2010/11, universities and colleges will be able to charge up to $£ 3,290$ for full-time, undergraduate courses; some will charge less. Don't worry though - you study first and pay when you are earning by taking out a Tuition Fee Loan - see below for more information.

\section{Tuition Fee Loan}

All eligible students are entitled to take out a Tuition Fee Loan. You can take out any amount up to the full amount charged for your course, and this will be paid direct to your college or university.

And you only start making repayments once you have left university or college and start earning more than $£ 15,000$ a year. See 'Repaying your Student Loans' below for more details.

\section{Living expenses}

There is help available towards living costs in the form of a Maintenance Loan (sometimes referred to as the student loan for maintenance) and the Maintenance Grant. There is also help from universities and colleges, in the form of bursaries.
Students with children or adult dependants and students with a disability, specific learning difficulty or mental health condition could also be eligible for extra help.

\section{Maintenance Loan}

The maximum amount of Maintenance Loan you can get to pay for living expenses will vary depending on your personal circumstances, such as where you study, where you live while studying, your income and that of your household, and the amount of any Maintenance Grant you receive.

You will usually receive your Maintenance Loan in three instalments throughout the year, one for each term.

And you only start making repayments once you have left university or college and start earning more than $£ 15,000$ a year. See 'Repaying your student loans' below for more details.

\section{Maintenance Grant}

There is extra financial help available in the form of the non-repayable Maintenance Grant. This could be worth up to $£ 2,906$ a year, depending on your personal circumstances. In 2010/11, up to two-thirds of all new students are expected to be eligible for a full or partial Maintenance Grant.

For students with eligibility for income support and other means-tested benefits such as housing benefit, there is the Special Support Grant. This is paid instead of the Maintenance Grant and your Department for Work and Pensions benefits will not be affected if you receive the Special Support Grant.

\section{Students who receive Education Maintenance Allowance}

You may be interested to know that students who get Education Maintenance Allowance (EMA) and then go on to university could qualify for the top level of grant in 2010/11, which may well ease some of the financial concerns you have when thinking about going to college or university.

N.B. EMA is an allowance which can be up to $£ 30$ a week paid to you when you are 16 and if you decide to stay on at school or go to college. You can get more information on EMAs at www.direct.gov.uk/ema 


\section{Bursaries}

Bursaries are extra financial help for students from the university or college they go to. You do not have to repay this help.

If you get the full Maintenance Grant and are going to a university charging the maximum tuition fee, you are guaranteed a minimum bursary of $£ 329$ a year. But you could get a lot more. The average annual bursary for students on full state support starting at university in $2010 / 11$ is $£ 900$. Some universities offer bursaries of up to $£ 3,250$ and some give a bursary to everyone, regardless of household income.

So, whoever you are, it's worth finding out what's on offer before you apply. Have a look at the websites of the universities and colleges you're interested in, or contact them directly. For more information on bursaries, go to www.direct.gov.uk/studentfinance

\section{Other sources of help}

If you have dependants (children or adult family members you have to support) or if you have a disability, you may be eligible for extra financial help which does not have to be paid back. There is more about this on page 15 .

\section{How can I pay for it?}

If you are considering how and when to return to education, you will want to think carefully about how you can afford it. Try to take a long-term view: think about the possibilities that higher education could open up for you - it can transform your career or help you take on a more satisfying and better-paid role. Remember that there is probably more help available than you might think.

Don't forget that you don't have to give up your job for higher education. You can always work and learn at the same time - many courses allow you to organise your studies around your job.

\section{Repaying your student loans}

Student loans are low interest, and you only start paying back the money once you have left university or college and are earning more than $£ 15,000$ a year.

The repayments are linked to your earnings, so the less you earn, the less you pay; the more you earn, the more you pay, and the sooner the loan is paid off. As an example, someone earning $£ 20,000$ would have to repay $£ 8.65$ a week, however much they owe. If at any time your earnings fall below $£ 15,000$ or you stop working, then your repayments will stop until you are earning enough again.

Additionally, students who enter repayment in April 2012 or later will be eligible for a repayment holiday of up to two years. This means that you will have the opportunity to put your payments on hold at a time of your choice, for example when buying a house or starting a family. Remember that only the payments are on hold and the interest will continue to accrue as normal.

Also, if you took out a student loan for the first time in 2006 or later, the Government will write off any student loan (except arrears) which is left unpaid 25 years after you have finished your course (plus any time taken as a repayment holiday).

\section{Support for part-time students}

There is help available for part-time students too. How much you could get depends on your income and how intensive your course is - basically what proportion of the full-time course you are doing each year. So if you are covering half of the course in the same time that the full-time course would be completed, you are studying at $50 \%$ of the full-time rate of study.

To get financial support, you usually need:

- to be studying at least $50 \%$ of the full-time rate, and

- to complete the whole course in no more than twice the time it would take to do the course full time. 
If so, you can apply for two grants, which you do not have to pay back:

- a Course Grant of up to $£ 265$ for books, travel and other course costs, and

- a Fee Grant of up to $£ 1,230$ (the amount of Fee Grant depends on the actual cost of the fees for the course, and how intensive the course is).

Both of these grants depend on how much income you have, and on your partner's income if you have one. You can apply for these grants for up to eight years, as part-time degree courses may take this long to complete - if you are studying part time on a course which lasts four years full time. Students who already have a degree cannot usually apply for this support.

\section{Other sources of help}

If you are doing a taster module, and you have not done any higher education before, your college might be able to help with the costs. Ask your college student services department for more information on this. If your course is in health care, you may get an NHS bursary - visit www.dh.gov.uk/en/ Publicationsandstatistics/Publications/Publications PolicyAndGuidance/DH_ 4006080 for a guide to 'Financial Help for Health Care Students'.

\section{Access to Learning Fund}

The Access to Learning Fund is available through universities and colleges and provides help for students in hardship who may need extra financial support for their course and to stay in higher education. You can get more information from your university or college, which will decide whether you are able to get this help, and if so how much they can offer.

\section{Professional and Career Development Loan}

A Professional and Career Development Loan (PCDL) is a bank loan. You make an agreement with a participating bank to borrow an amount between $£ 300$ and $£ 10,000$. Then once you've stopped studying, you pay it back in the normal way.

The difference with a PCDL is that the Learning and Skills Council (LSC) pays the interest on the loan while you're studying - and for one month afterwards.

After this, you'll pay interest at the rate fixed when you took out the loan. Interest rates on the loans are set so they're competitive with other 'unsecured' personal loans that are commercially available.

Full details are available on the Directgov website at www. direct.gov.uk/pcdl or call the PCDL information line on 0800585505 for help andadvice or to order a PCDL application pack. 


\section{I'm disabled -}

\section{is there extra help available?}

Disabled Students' Allowances help with the extra costs you may have as a direct result of your disability, mental health condition or specific learning difficulty. How much you could get does not depend on your income or that of your family. You do not have to repay this help. The amount you can receive should you need a nonmedical personal helper is $£ 20,520$ a year for a full-time course and $£ 15,390$ a year for a part-time course.

\section{How would returning to Higher Education affect my benefits?}

The amount of some means-tested benefits you get may be affected. Ask for advice from the student finance adviser at your university or college.

\section{Where can I get more information?}

For more information on student finance you can visit www. direct.gov.uk/studentfinance, call freephone 08005878500 to order the booklet 'How to Get Financial Help as a Student', or contact the Student Finance England helpline on 08453005090 .

If you have a child or children who are dependent on you, there is the Childcare Grant which is worth up to $£ 148.75$ a week for one child or $£ 255$ a week for two or more children. There is also a Parents' Learning Allowance worth up to $£ 1,508$ a year. How much you could get depends on your income and that of your dependants. You do not have to repay this help.

You can also apply for Child Tax Credit from HM Revenue and Customs.

If you have a partner or another adult (usually a member of your family) who depends on you financially, you may be able to get an Adult Dependants' Grant of up to $£ 2,642$ a year. How much you could get depends on your income and that of your dependants. You do not have to repay this help. 


\section{Planning $\mathrm{my}$ next steps}

With all those options, you will need

to think carefully before you start,

and all the way through the process

of applying for a course.

\section{Step 1: Where am I now?}

\section{Assess your current situation \\ Your job: \\ - What job are you doing? \\ -What are the prospects? \\ - What do you like about the job? \\ - What are you aiming for? \\ - Is anything holding you back?}

\section{Your personal life:}

- Are you married or do you have a partner?

- Do you have children?

- Who looks after them?

- Does anyone depend on you for financial support?

\section{Step 2: What is my financial situation?}

Gather together your bills for a few months, and work out how much you need to spend each month. Whether you are planning to work part time while you study, or give up work to study full time, you need to work out what you will have coming in and how much will be going out. Don't forget to allow for one-off emergency expenses such as household repairs or medical costs.

\section{Then there are a few things you need to do:}

- See where you could reduce your outgoings.

- Go over your budget with anyone who will be affected, such as other members of your family.

- Add in the extra costs for studying - travel, books, stationery and so on.

Use the Student Finance Calculator to help you plan your finances: www.direct.gov.uk/studentfinance

\section{Step 3: What subject or qualification?}

If you are aiming for a specific job or career, you will need to find out which qualifications you need.

Research by talking to colleagues and employers. Make a note of what they say about the qualifications and experience required.

Contact learndirect (www.learndirect.co.uk) for information on finding career advice, local colleges and universities, and for help on choosing the right course.

You can also visit the Unistats website (www, unistats.com) which brings together official information on UK higher education and could help you make choices about what and where to study. It enables you to:

- compare UCAS points and other information for different subjects and institutions

- find out about the achievements of recent students and discover what sort of jobs they are doing six months after finishing

- read what over 177,000 students felt about the quality of their higher education experience.

\section{Step 4: Find suitable courses}

Visit the UCAS and ICDL (International Centre for Distance Learning) websites at www.ucas.com and www-icdl.open.ac.uk

- Make a note of all the courses that look interesting and that will help you progress to the job or career you want.

- Write down important information such as the course title, code, university or college name, address and contact details.

- Check the qualifications needed and find out if you need to do any extra courses first.

- Depending on the qualifications you already have and the course you want to do, you may want or have to do an Access programme. This helps you prepare yourself for higher education, and takes two years part time or one year full time. Visit www.ucas.com/access or www.accesstohe.ac.uk

- Get in touch directly with your local university or college. Visit university finder at www.hero.ac.uk to find universities and colleges near you.

- Check the deadline for applying - this could be different for different courses. 


\section{Step 5: Narrow down your choices}

There is a limit of five full-time courses you can apply to. And although there is no limit if you want to study part time or through flexible learning, it makes sense to narrow them down to the ones that really interest you and meet your needs.

- Start by ordering prospectuses for all the colleges and universities you are interested in, and check the content of each course carefully. Do the topics interest you? Are they relevant to what you need?

- Try to visit as many of them as you can - you can get details of their open days from each college or university. Take the opportunity to talk to students there and find out what the place is really like.

- If you can't visit, call the admissions office to discuss your plans. Their contact details will be on the university or college website.

\section{Step 6: Apply for your courses}

If you have the right qualifications, or after you have done your Access programme, you can begin applying. For full-time courses, you apply through UCAS, or for part-time or flexible courses apply direct to the university or college. You also apply direct to the college for Access programmes.

\section{Step 7: Apply for financial help}

- You can apply online at www. direct.gov.uk/studentfinance or you can download the application forms from this website. You can also contact your local authority or Student Finance England for an application form.

- If you have applied for an Open University course, contact the Open University instead, as they have their own application forms for fee grants, course grants and Disabled Students' Allowances.

- Find out what you might be entitled to, and make sure you apply for all the help you can.

- Fill in the forms as fully as possible and return them on time so that you get your money at the start of your course.

\section{Step 8: Make your final choices}

You will receive offers of places on different courses during May to July. These will either be conditional (depending on getting certain grades on courses you are doing now) or unconditional (you definitely have a place).

If you are applying for full-time courses, you will need one first choice plus a back-up choice. Think carefully, as if you miss the grades for your first choice you will be expected to take up the backup place.

\section{Step 9: Start your course}

That's all that's left to do! Your local authority will let you know what financial help you are entitled to before the course starts so you will be able to finalise your budget.

When you arrive at college or university:

- register in your department

- collect your student loan - it is normally paid straight into your bank, but you may need to collect a cheque

- buy any course books you need

- join the clubs and societies that interest you. 
18 поN'т SтOP. Aimhigher...

Case study

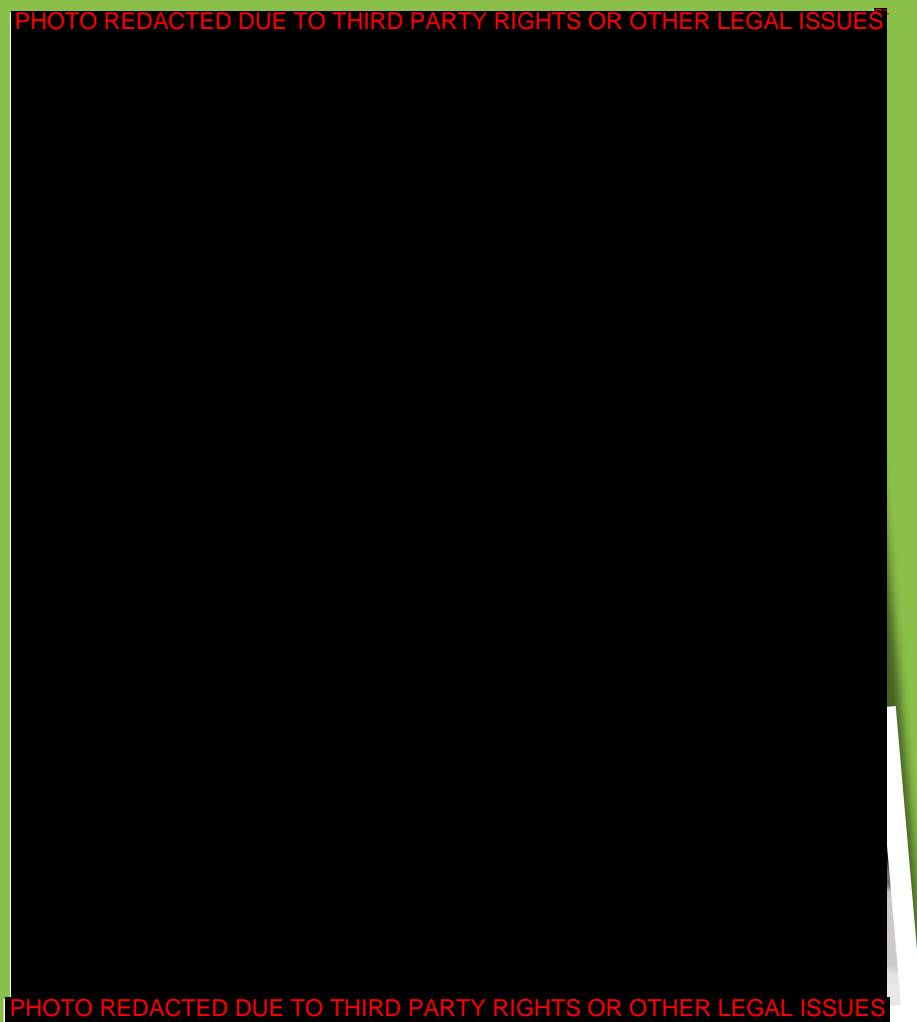

Name: Mark Laird

Age: 36

Gourse: Foundation Degree in Computing, Lancaster University

Mark left school after having done his GCE O levels, and went on to do factory and technician work. He decided to return to study to gain a qualification in Computing, which would help to further his career. He started off doing an HNC but then transferred to the Foundation Degree when he realised that it would bring him nearer to his long-term goal.

The Foundation Degree was a flexible, vocational option that suited Mark's aspirations. It included world-class computing experience in a business environment and up-to-date course modules that would be relevant to the work he would go on to. Equally, the mix of students and the fact that the university was near home meant that the course was ideal for Mark.

Since returning to study, Mark has been given the opportunity to complete a Shell Technology Enterprise Project through the Pendle Enterprise Trust, which would involve developing software in a business environment. He is confident that he will receive other opportunities to work in the software field as a direct result of his Foundation Degree.

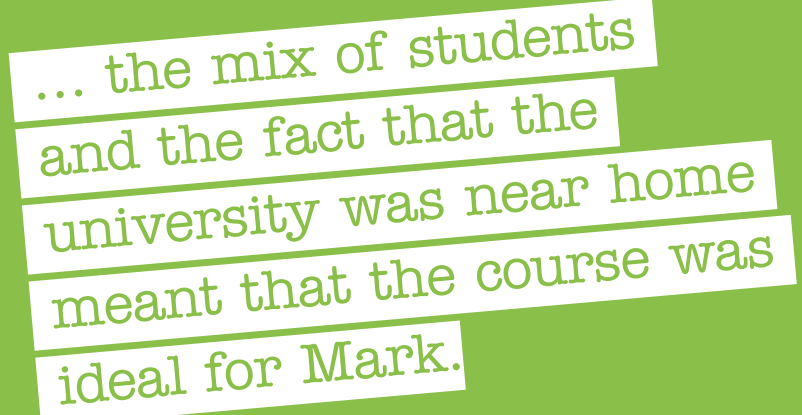


Your notes 


\section{Where can I get \\ more information?}

Try the following websites to find out more about higher education

\section{General}

\section{Aimhigher \\ Information on getting back to higher education: www.direct.gov.uk/uni}

\section{UCAS}

The UCAS website gives a list of full-time courses and help on how to apply at www.ucas.com or call 08714680468 for course information.

\section{Unistats}

The Unistats site www.unistats.com brings together official information on UK higher education and could help you make choices about what and where to study.

\section{Foundation Degrees}

Information and useful links on Foundation Degrees: www.findfoundationdegree.co.uk and www.fdf.ac.uk

\section{Need more copies?}

You can get more copies of this booklet by downloading it for free at www.bis.gov.uk/publications or by calling 08450150010 or emailing publications@bis.gsi.gov.uk and quoting URN 09/1160.

\section{Need a different format?}

You can also obtain this leaflet in audio format by calling the freephone number above.

(c) Crown copyright 2009. Produced for the Department for Business, Innovation and Skills, September 2009

You may copy extracts from this document for educational purposes as long as you mention the source.

URN 09/1160

\section{$75 \%$ recycled \\ This leaflet is printed} on $75 \%$ recycled paper

\author{
Financial information \\ For online applications for student \\ finance, entitlement calculators and \\ information, advice and guidance \\ on all aspects of student finance, \\ visit www.direct.gov.uk/studentfinance
}

\section{About being a student}

\section{INUS}

Represents UK students, providing benefits, research and information: www.nusonline.co.uk

\section{Uni4me}

A practical guide to university life and advice on how to apply:

www.uni4me.co.uk

\section{Studentzone}

Information and advice on a wide range of student issues:

www.studentzone.org.uk 